promotes the tumorigenic potential of cells lacking endogenous p 53 protein. Missense mutations can generate mutant p53 protein, which is more stable than wild type p53 protein and can sequester normal protein into inactive oligomeric complexes. ${ }^{29}$ Such mutant proteins effectively act like the oncogene products of the DNA tumour viruses, which also form complexes with p53 protein (and other tumour suppressor proteins) to abrogate its cellular activity. ${ }^{10}$ In cervical carcinomas positive for human papillomavirus the E6 oncogene of human papillomavirus types 16 and 18 binds to p53 protein in infected cells to promote tumorigenesis. ${ }^{11} \mathrm{~A}$ further class of mutation has recently been described in some breast cancers, in which $\mathrm{p} 53$ protein is sequestered in the cytoplasm rather than being transported into the nucleus, thereby preventing it from functioning in its correct cellular compartment. $^{12}$

More recently, both mutant and wild type p53 protein has been shown to form complexes with the product of a cellular proto-oncogene called mdm-2.13 High concentrations of mdm-2 prevent normal p53 protein from activating gene transcription, so the transforming action of an oncogene (mdm-2) might be explained by its ability to inactivate the product of a tumour suppressor gene (p53). Cancers have indeed been described that are normal for p 53 but in which $\mathrm{mdm}-2$ is overexpressed ${ }^{10}$ - the number of tumours that involve dysfunction of p53 protein may therefore be even greater than studies of mutation in the p53 gene alone suggest. $^{2}$

Screening for mutations of $\mathrm{p} 53$ is already of diagnostic and prognostic value for patients with cancer and families at increased risk of cancer, although such information brings with it profound socioeconomic and ethical implications. Whether p53 can be a viable therapeutic target remains to be seen. Eventually, it may be possible to deliver normal copies of p53 to tumour cells in vivo to induce apoptosis ${ }^{14}$ or differentiation ${ }^{15}$ or even to restore sensitivity to cytotoxic agents, ${ }^{8}$ although considerable theoretical and practical difficulties remain. ${ }^{16}$ Pharmaceutical intervention may target the altered conformation of mutant proteins so that the function of p53 in normal cells is left unaffected.

The p53 gene blurs the previously sharp conceptual division between the oncogenes and the tumour suppressor genes both functionally (certain mutant $\mathrm{p} 53$ proteins can be dominantly transforming) and also mechanistically (by its interaction with known viral and cellular oncogenes). p53 therefore seems likely to yield profound insights into the basic molecular mechanisms of cancer.

RICHARD G VILE Research fellow

Biology of Metastasis Laboratory, Imperial Cancer Research Fund, London WC2A 3PX

1 Donehower LA, Bradley A. The tumor suppressor p53. Biochim Biophys Acta 1993;1155:181-205. 2 Vogelstein B, Kinzler K. p53 function and dysfunction. Cell 1992;70:523-6.

3 Harvey M, McArthur MJ, Montgomery CA, Bradley A, Donehower LA. Genetic background alters the spectrum of tumours that develop in $p 53$-deficient mice. FASEB $f$ 1993;7:938-43. 4 Collins MKL, Lopez Rivas A. The control of apoptosis in mammalian cells. Trends Biochem $S_{c i}$ 1993;18:307-9.

5 Clarke AR, Purdie CA, Harrison DJ, Morris RG, Bird CC, Hooper ML, et al. Thymocyte apoptosis induced by $p 53$-dependent and independent pathways. Nature 1993;362:849-52.

6 Lowe SW, Schmitt EM, Smith SW, Osborne BA, Jacks T. p53 is required for radiation-induced apoptosis in mouse thymocytes. Nature 1993;362:847-9.

7 Lane DP. p53, guardian of the genome. Nature 1992;358:15-6.

8 Lowe SW, Earl Ruley H, Jacks T, Housman DE. p53-dependent apoptosis modulates the cyto , Earl Ruley H, Jacks T, Housman DE.

Zambetti GP, Levine AJ. A comparison of the biological activities of wild-type and mutant $p 53$. FASEB f 1993;7:855-65.

10 Levine AJ. The tumor suppressor genes. Ann Rev Biochem 1993;62:623-51.

11 Vousden K. Interactions of human papillomavirus transforming proteins with the products of rumour suppressor genes. FASEB f 1993;7:872-9.

12 Moll UM, Riou G, Levine AJ. Two distinct mechanisms alter $p 53$ in breast cancer: mutation and nuclear exclusion. Proc Natl Acad Sci USA 1992;89:7262-6.

13 Momand J, Zambetti GP, Olsen DC, George D, Levine AJ. The $m d m-2$ oncogene product forms a complex with the $p 53$ protein and inhibits $p 53$ mediated transactivation. Cell 1992;69:1237-45.

14 Fujiwara T, Grimm EA, Mukhopadhyay T, Cai DW, Owen-Schaub LB, Rother JA. A retroviral wild-type $p 53$ expression vector penetrates human lung cancer spheroids and inhibits growth by inducing apoptosis. Cancer Res 1993;53:4129-43.

15 Chen PL, Chen Y, Bookstein R, Lee WH. Genetic mechanisms of tumor suppression by the human p53 gene. Science 1990;250:1576-80.

16 Vile RG, Russell SJ. Gene transfer technologies for the gene therapy of cancer. Gene Therapy (in press).

\title{
Information management and patient privacy in the NHS
}

\author{
Confidentiality must be better protected, probably by statute
}

Last year the NHS Management Executive launched an ambitious project to unify health service information systems. ${ }^{1}$ Its aim is to set free all the health information currently imprisoned on isolated systems throughout the health service and allow it to travel to wherever decisions are being made. The benefits of sharing information across the health service are undeniable. General practitioners, specialists, and other health professionals will no longer have to conduct consultations without notes or investigation results; purchasers will have the information they need to contract accurately for services; and audit will be easier, quicker, and more streamlined. The strategy could also, however, make it far more difficult than it is now to protect patients' confidentiality and privacy. So far these problems have attracted little attention from most NHS professionals.

A seminar organised by the BMA's information technology working group heard last week that most doctors are not only ignorant of the strategy's implications for privacy but also unaware of the objectives of the strategy itself. A survey done in April this year by the management executive showed that only a fifth of general practices knew it existed. ${ }^{2}$ Few of the speakers and even fewer of the invited audience could name even one of the strategy's five key principles, a reflection of the management executive's failure to make NHS professionals aware of the strategy.

The essentials are that by 1995 everyone in the country will be identified by a new NHS number. This will be recorded along with other personal information-name, address, date of birth, sex, and registered general practitioner-in one of a set of administration registers. Each administration register will hold details on everyone living in a particular geographical area and they will all be linked. The local register will provide the core data for local general practice lists, hospital administration systems, and family health sevice association registers, removing the need for each system to duplicate patient data. And when patients move outside their local area the linkage of all administration registers will allow a distant hospital or practice to access the patient's details. Eventually a nationwide computer network will be in place allowing family health service associations, district health authorities, general practitioners, community units, hospitals, and others to share patient information. Clinical details, including signs, symptoms, diagnoses, and prescribed treatment will be coded from a nationally agreed thesaurus based 
on the Read codes, which are already used in primary care and other areas of the NHS. Access to any of this information will be possible, however, only if computer systems throughout the NHS are compatible. The timetable is short. The central component of the network is planned for next year, and the whole strategy could be complete by 2000 .

The project is huge, ambitious, and driven largely by the internal market's need for high quality information for contracting; at the moment it is going ahead with little input from the health professionals whose duty it is to protect sensitive patient information. Last week's seminar heard that patient privacy is threatened by both the scale of the projectmore information, and more people with access to it-and its universal nature. A large database with up to date details, including names and addresses of everyone in Britain, would be a tempting target for many commercial and governmental organisations. It also heard that current laws are inadequate to protect patient confidentiality in this sort of system.

Many concerns relate to computerisation in general: the theft of computers, hacking, computer viruses, inadvertently sending patient details to the wrong person, and the depersonalised nature of information on a computer screen. Anthony Nowlan, a clinical research fellow at Manchester University's department of computer science, told the seminar that without the personal quality of paper notes it was easier to breach confidentiality by, for example, forgetting to $\log$ off a ward terminal or leaving passwords taped to the front of it. Finally, of course, computers allow searches to be conducted among vast amounts of data in ways that would simply be impracticable with paper records.

As important are issues of ownership, control, and use of any national network and how effective current data protection laws would be in preventing abuse of the information on the network. Simon Davie, director general of Privacy International, an independent organisation of experts committed to protecting personal privacy, warned the seminar of the dangers of relying on the integrity of governments to prevent abuse of such a uniquely comprehensive, up to date, and reliable population register. It is not only possible, he said, but probable that without specific safeguards the system would end up linked with other services such as social services, education, and law enforcement, none of which are governed by workable ethical codes. A health register could also be used as the basis for a national identity system, with all its attendant risks of invasion of civil liberty and national surveillance.

The use of electronic information about people is governed by the Data Protection Act 1984. The eight principles of the act set conditions for registered users such as NHS trusts, family health services associations, and general practitioners.
One states that personal data can be used only for the purposes it was registered for and given only to the people described in the register entry. There are, however, few restrictions on who can be named. For example, it would be theoretically possible for a trust hospital to alter its register entry to allow it to divulge health information to a health insurance company. Trusts obviously have a duty of confidentiality to patients but that duty is not governed by statute. The data protection registrar, who administers the act, said in his 1993 report to parliament, "I have doubts whether common law, nonstatutory guidance, or professional codes will be sufficient (to prevent compromising the confidentiality of sensitive health information). The common law duty of confidence is complex and does not appear to have been tested in circumstances such as the wide use of health information in the NHS." 3

In 1990 the BMA published, on behalf of an interprofessional working group chaired by Sir Douglas Black, a code of confidentiality governing the use and disclosure of personal health information. ${ }^{4}$ It emphasises that patient information must be held only for the purposes of health care and disclosed only to those who need to know it. The data protection registrar has been urging the government since 1991 to adopt this code, which would go a long way to protect patient privacy. Instead the Department of Health promised its own guidelines. These have yet to be published.

It is clear that there is a tension between sharing information, with all its benefits for patients and for health professionals, and the fundamental human right of personal privacy. What the balance between the two should be is debatable, but doctors and their patients need to be well informed about the strategy and its implications so they can shape the debate. Meanwhile, the British Medical Association will be campaigning for public awareness and for a code of confidentiality that is legally binding, effectively policed, and the ultimate responsibility of the secretary of state for health.

Assistant editor, $B M \mathcal{F}$

ALISON TONKS

1 Information Management Group, NHS Management Executive. An information management and technology strategy for the NHS in England. London: Department of Health, 1992

2 Social Surveys (Gallup Poll) Ltd. Computerisation in GP practices: 1993 survey. Leeds: NHS Management Executive, 1993.

3 Data Protection Registrar. Ninth report. London: HMSO, 1993.

4 Inter-Professional Working Group. Confidentiality of personal health information. London: BMA, 1990.

\section{Correction}

\section{The Gardner hypothesis}

Owing to an editorial error Hazel Inskip's address was omitted from her editorial in last week's $B M \mathcal{F}$ (6 November, $\mathrm{p} 1155)$. Dr Inskip works at the MRC Environmental Epidemiology Unit, Southampton General Hospital, Southampton SO9 4XY. 